\title{
Fiscal decentralization, public spending, and economic growth in China
}

\author{
Tao Zhang ${ }^{\mathrm{a}, \mathrm{b}}$, Heng-fu Zou ${ }^{\mathrm{a}, \mathrm{b}, *}$ \\ anstitute of Advanced Studies, Wuhan University, Wuhan, 430072 China. \\ ${ }^{\mathrm{b}}$ Policy Research Department, World Bank, Washington, DC 20433, USA
}

Received 1 October 1995; received in revised form 1 April 1997; accepted 1 May 1997

\begin{abstract}
This study of China demonstrates how the allocation of fiscal resources between the central and local governments has affected economic growth since reforms began in the late 1970s. We find that a higher degree of fiscal decentralization of government spending is associated with lower provincial economic growth over the past fifteen years. This consistently significant and robust result in our empirical examinations is surprising in light of the argument that fiscal decentralization usually makes a positive contribution to local economic growth. (C) 1998 Elsevier Science S.A.
\end{abstract}

Keywords: Fiscal decentralization; Public spending; Growth; Chinese economy

JEL classification: E62; H2; H4; H5; O4; R5

\section{Introduction}

Many developing countries and transition economies have a mandate to decentralize aspects of their public finance. At the same time, many developed economies such as the United States, the United Kingdom, and Canada are reviving debates on devolution. Decentralizing revenue raising and spending decisions is seen as a way to improve the efficiency of the public sector, cut the budget deficit, and promote economic growth (Bird, 1993; Bird, Wallich, 1993;

*Corresponding author. Room N 10-075, the World Bank, 1818 H St. NW, Washington, DC 20433, USA. Fax: 001202522 1154; e-mail HZOU@Worldbank.Org 
Bahl, Linn, 1992; Gramlich, 1993 and Oates, 1993). The argument is that decentralization will increase economic efficiency because local governments are better positioned than the national government (Oates, 1972) to deliver public services that match local preferences and needs, and that over time, efficiency gains will lead to faster local as well as national economic growth.

Such conventional wisdom is reflected in numerous studies on intergovernmental fiscal relations in China (Bahl, Wallich, 1992; World Bank, 1990, 1992). Many proposals favor assigning more revenue and expenditure responsibilities to local governments. However, in China there is concern that decentralization has been implemented too fast and has gone too far, and that this is threatening macroeconomic control and stability (Wang, Hu, 1993; World Bank, 1995, 1996). It seems that national priorities in public spending have often been crowded out by local public projects.

Despite the mounting concern, there have been very few empirical studies of the relationship between fiscal decentralization and economic growth for developing countries in general, and for China in particular. This paper explores how the allocation of fiscal resources between the central and local governments has been associated with economic growth in China since the reforms of the late 1970s.

First, we will summarize the trend in fiscal allocation between the central and local governments in Section 2 and then empirically test the impact on economic growth of spending by different levels of government using provincial panel data during the period 1978-1992 in Section 3. Section 4 concludes the paper.

\section{Trend in fiscal allocations between central and local governments: 1978- 1992}

Since the late 1970s, China has gone through several rounds of fiscal reforms in an effort to decentralize its fiscal system and fiscal management (World Bank, 1990; Wong et al., 1993; Zhou, Yang, 1992). Can we say that the fiscal system is now more decentralized? The following examination suggests that the question should be answered very carefully.

\subsection{Overall fiscal status}

In China, official government spending appears in three ways: budgetary spending, extra-budgetary spending, and consolidated spending, which is the sum of budgetary and extra-budgetary spending.

Fig. 1 shows that budgetary spending accounted for $18.3 \%$ of GDP in 1992 compared to $30.8 \%$ in 1978 . Although rises were insignificant from 1978 to 1979 ,

\footnotetext{
${ }^{1}$ Local governments include all subnational governments in this paper.

${ }^{2}$ The data used in our calculation are described in the data appendix A.
} 


\section{Share of Budgetary Spending Relative to GDP}

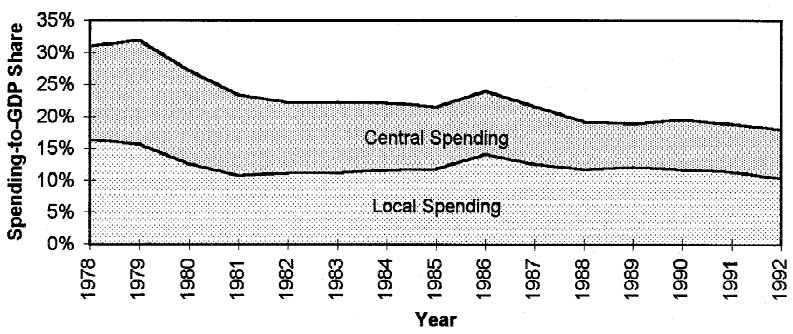

Share of Extra-budgetary Spending Relative to GDP

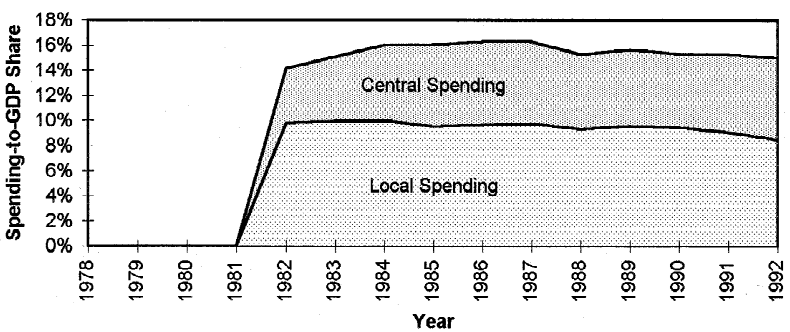

Share of Consolidated Spending Relative to GDP

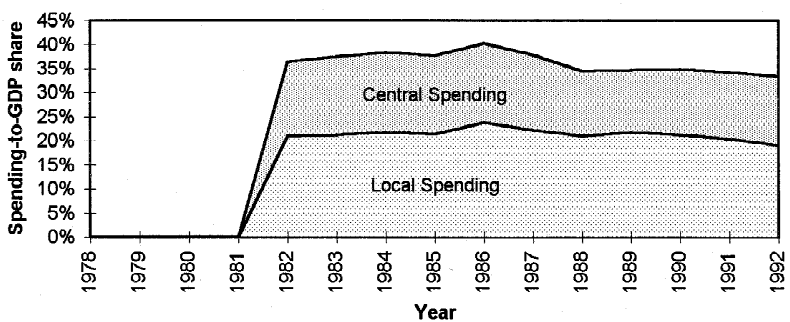

Source : See the data appendix.

Fig. 1. Shares of spending.

1985 to 1986 , and 1988 to 1989 , the budgetary spending-to-GDP ratio declined continuously since the beginning of the reform in 1978. As for the share of extra-budgetary spending relative to GDP, changes were rather limited, and it rose from $14.2 \%$ in 1982 to $15.2 \%$ in 1992 . $^{3}$ Consolidated budgetary spending as a share of GDP shows an inverted U-shape. It first increased during 1982-86 from

\footnotetext{
${ }^{3}$ The central and provincial aggregate data on extra-budgetary spending became available in 1982.
} 
$36.4 \%$ in 1982 to $40.4 \%$ in 1986 (except for a small decline in 1985), and then declined during 1986-92 to $33.5 \%$ in 1992 . This shows that overall government fiscal spending as a share of GDP, and especially budgetary expenditures, fell during the reform period.

\subsection{Relative fiscal status between the central and local governments}

In the literature on fiscal federalism, fiscal decentralization is measured by the relative sizes of local spending and revenue collection and central spending and revenue collection. In China, however, the relative size of local revenue collection is not a good indicator of decentralization. For many years in our sample period, most tax revenues were levied by the center, even though they were mainly collected by local governments. Locally collected revenues generally were not spent locally, so they did not reflect local tax autonomy. We take this into account in this study by focusing on the relative size of government spending between the central and local governments.

Fig. 1 shows spending by local governments, including the spending financed by transfers from the central government, was $16.4 \%$ of GDP in 1978. This accounts for $53.1 \%$ of total budgetary spending by both the central and local governments in the same year. These shares became 10.3 and $57.4 \%$ respectively in 1992, indicating slight progress in budgetary decentralization. The share of local budgetary spending out of total budgetary spending first declined to $46.0 \%$ in

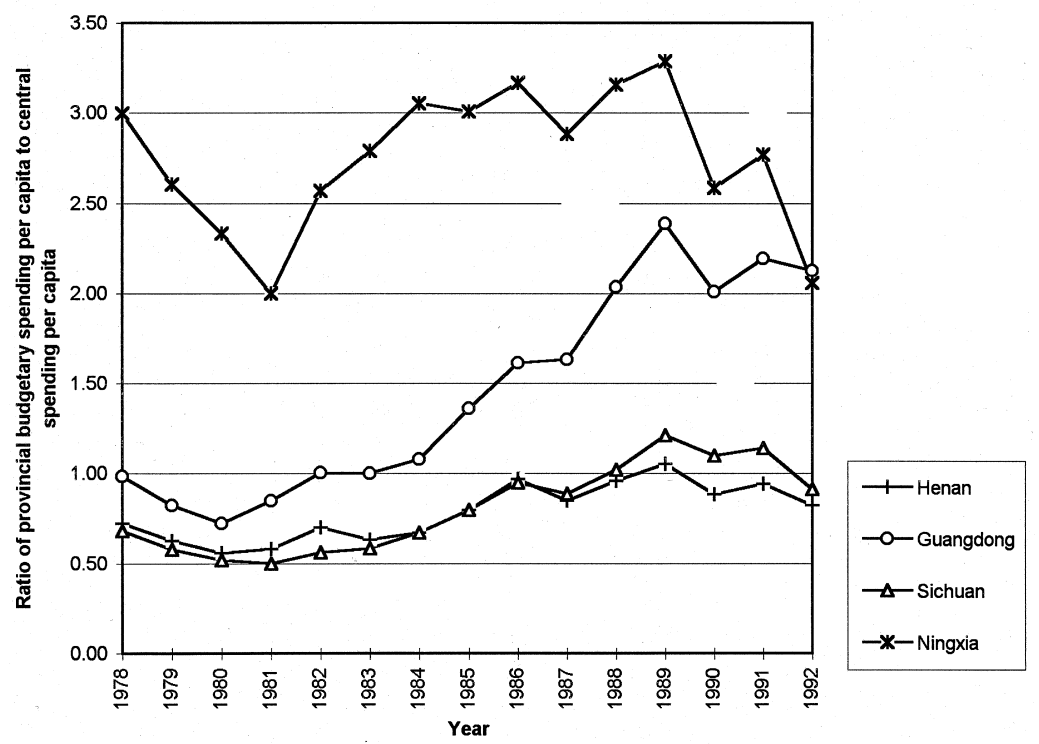

Fig. 2. Fiscal decentralization in selected provinces. 
1981, before climbing to $63.7 \%$ in 1989 and subsequently declining again, almost to its original level. Overall, the share of local budgetary spending increased over most of the decade.

By contrast, local extra-budgetary spending demonstrated a trend of fiscal centralization over the entire post-reform period. As Fig. 1 shows, local governments spent $9.8 \%$ of GDP as extra-budgetary expenditures in 1978, and $8.4 \%$ in 1992; the share of local extra-budgetary spending in total extra-budgetary spending declined from $69.1 \%$ in 1982 to $56.4 \%$ in 1992. If we combined budgetary and extra-budgetary spending, the local share of consolidated spending fluctuated up and down from $57.5 \%$ in 1982 to $62.5 \%$ in 1989 and back to $56.9 \%$ in 1992 .

\subsection{Fiscal decentralization from the provincial perspective}

First, there is significant variation between provinces in terms of fiscal status. ${ }^{4}$ From 1980 to 1992 , the ratio of budgetary spending to provincial income ranged from $9.0 \%$ in Jiangsu (a coastal province) to $40.5 \%$ in Ningxia (an inland autonomous region), indicating a general tendency for provincial governments to participate less in developed areas and more in under-developed areas. Further complications are observed when considering the three metropolitan cities, Beijing, Tianjin, and Shanghai, which represent high ranks in per capita income and above average ratios of budgetary spending to provincial income.

Second, great variations in fiscal decentralization can be found between provinces. As Table 1 shows, during the period 1978-92, the average ratio of provincial budgetary spending to central budgetary spending ranged from 0.01 in Ningxia to 0.09 in Guangdong (known as a leading province in economic reforms). Because Chinese provinces vary in terms of geographic area and population size, we adjust the fiscal-decentralization measure in per capita terms. Accordingly, the ratio of per capita provincial budgetary spending to per capita central budgetary spending was as low as 0.78 in Henan (an inland province) and as high as 4.31 in Beijing (the nation's capital). ${ }^{5}$ For extra-budgetary spending during 1986-92, the average province-to-center ratio in Ningxia was only 5\% of that in Liaoning, one of China's heavy industrial centers. Since extra-budgetary spending has been financed mostly by the revenues and profits of state-owned enterprises during our sample period, we adjust the measure of decentralization for the income size. The ratios of provincial extra-budgetary spending to central extra-budgetary spending, each expressed relative to income, varied from 0.71 in Guizhou (a mountainous minority province) to 2.84 in Beijing. In terms of the ratio of per capita provincial consolidated spending to per capita central consolidated

\footnotetext{
${ }^{4}$ Of the total thirty provincial areas in China, two provincial areas, Tibet and Hainan, are excluded due to their special status. For a complete list of the twenty-eight provincial areas used in this study, see the data Appendix A.

${ }^{5}$ The central per capita spending is the central spending divided by the total population of China.
} 
Table

China: Income growth and provincial fiscal decentralization, 1978-1992

\begin{tabular}{|c|c|c|c|c|c|c|}
\hline & $\begin{array}{l}\text { Real growth rate } \\
\text { of provincial } \\
\text { income }\end{array}$ & $\begin{array}{l}\text { The ratio of } \\
\text { provincial } \\
\text { budgetary } \\
\text { spending to } \\
\text { central }\end{array}$ & $\begin{array}{l}\text { The ratio of } \\
\text { provincial extra- } \\
\text { budgetary } \\
\text { spending to } \\
\text { central }\end{array}$ & $\begin{array}{l}\text { The ratio of per } \\
\text { capital provincial } \\
\text { budgetary } \\
\text { spending to per } \\
\text { capita central } \\
\left(D C_{\text {be }}\right)\end{array}$ & $\begin{array}{l}\text { The ratio of } \\
\text { provincial extra- } \\
\text { budgetary spending } \\
\text { to central, } \\
\text { expressed relative } \\
\text { to income }\left(D C_{\text {ebe }}\right)\end{array}$ & $\begin{array}{l}\text { The ratio of per } \\
\text { capita provincial } \\
\text { consolidated } \\
\text { spending to central } \\
\left(D C_{\text {cbe }}\right)\end{array}$ \\
\hline Provincial areas & $\begin{array}{l}\text { Average } \\
(1978-1992)\end{array}$ & $\begin{array}{l}\text { Average } \\
(1978-1992)\end{array}$ & $\begin{array}{l}\text { Average } \\
(1986-1992)\end{array}$ & $\begin{array}{l}\text { Average } \\
(1978-1992)\end{array}$ & $\begin{array}{l}\text { Average } \\
(1986-1992)\end{array}$ & $\begin{array}{l}\text { Average } \\
(1986-1992)\end{array}$ \\
\hline Three metropolitan cities & $8.57 \%$ & 0.04 & 0.07 & 4.15 & 2.38 & 5.94 \\
\hline Beijing & $9.07 \%$ & 0.04 & 0.07 & 4.31 & 2.84 & 6.45 \\
\hline Tianjin & $8.18 \%$ & 0.03 & 0.04 & 3.91 & 2.20 & 4.71 \\
\hline Shanghai & $8.45 \%$ & 0.05 & 0.10 & 4.24 & 2.11 & 6.67 \\
\hline Coastal areas & $11.74 \%$ & 0.06 & 0.08 & 1.29 & 1.37 & 1.70 \\
\hline Liaoning & $11.24 \%$ & 0.07 & 0.12 & 2.03 & 2.14 & 3.00 \\
\hline Hebei & $8.89 \%$ & 0.06 & 0.07 & 1.02 & 1.42 & 1.20 \\
\hline Jiangsu & $12.75 \%$ & 0.06 & 0.10 & 1.01 & 1.24 & 1.44 \\
\hline Zhejiang & $13.67 \%$ & 0.05 & 0.07 & 1.17 & 1.27 & 1.64 \\
\hline Fujian & $12.62 \%$ & 0.04 & 0.04 & 1.41 & 1.34 & 1.61 \\
\hline Shandong & $10.83 \%$ & 0.07 & 0.09 & 0.92 & 1.12 & 1.18 \\
\hline Guangdong & $12.19 \%$ & 0.09 & 0.09 & 1.45 & 1.10 & 1.81 \\
\hline Inland areas & $8.68 \%$ & 0.05 & 0.05 & 1.19 & 1.34 & 1.36 \\
\hline
\end{tabular}




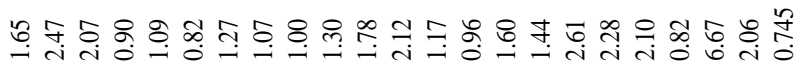

乐

చุ

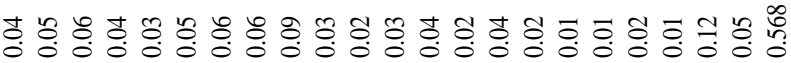

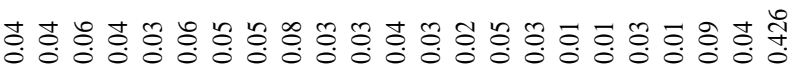

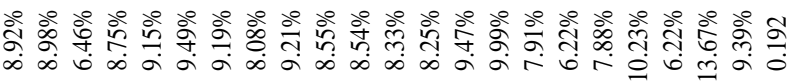

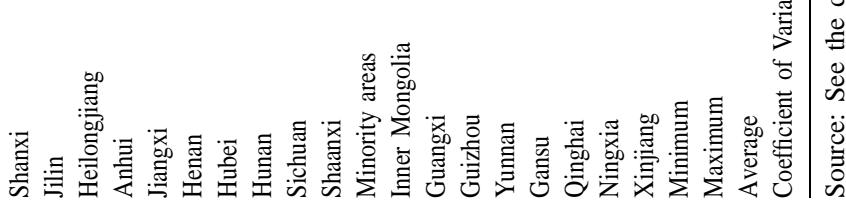


spending, the degree of fiscal decentralization varied from 0.82 in Henan to 6.67 in Shanghai, China's largest metropolitan city.

Third, fiscal decentralization within a province also varies over time, as shown in Fig. 2. Guangdong, a coastal province favored by the central government policies and among the first to undertake economic reforms in 1978, experienced the greatest fiscal decentralization. In terms of the ratio of per capita provincial budgetary spending to per capita central budgetary spending, Guangdong had an annual average increase of 6.6\% during 1978-92. At the other extreme, Ningxia, one of the eight minority provincial areas, experienced hardly any increase in its per capita budgetary spending relative to the central government. In fact, this ratio decreased by $1.6 \%$ annually during this period. Between Guangdong and Ningxia are mostly inland provinces. In terms of the ratio of provincial per capita budgetary spending relative to the central government, the annual growth rate was $3.0 \%$ in Sichuan, the most populous province in China, and $1.8 \%$ in Henan, a political and economic center of ancient China.

\subsection{Summary}

The above discussion suggests that fiscal reform in China does not yield a clear pattern of fiscal decentralization on the spending side: (1) budgetary spending became more decentralized since 1978; (2) extra-budgetary spending, however, showed a decreasing local share during the entire reform period; (3) the share of local consolidated spending rose and fell; (4) fiscal decentralization varied across provinces and over time. In the following section, we will quantify the impact of fiscal decentralization measures on provincial economic growth.

\section{Empirical estimations with provincial-level data}

\subsection{Variables and estimations}

Our empirical estimations are based on annual data from 1980 to 1992 for 28 provinces. The dependent variable is the provincial income growth rate in real terms. ${ }^{6}$ The explanatory variables fall into four categories:

1. Production inputs, including investment and labor.

2. Measures of fiscal decentralization of spending.

\footnotetext{
${ }^{6}$ Provincial income is defined as the provincial equivalent of national income (Guomin Shouru), which measures net provincial output according to Chinese statistics.
} 
3. Measures of the composition of central and provincial budgetary expenditures.

4. Other variables, such as the tax rate, foreign trade, and the inflation rate.

We define the following variables in our estimations:

- $Y=$ the real growth rate of provincial income.

- $L=$ the growth rate of the provincial labor force.

- $I=$ the provincial investment rate, measured by the ratio of investment (accumulation in fixed assets and circulating funds) to provincial income.

- $F=$ the degree of openness of the provincial economy, measured by the share of total volume of foreign trade (the sum of exports and imports) in provincial income.

- $T A X=$ the degree of distortion in the provincial economy, measured by

$C T$ : the ratio of central budgetary revenue to national GDP, which is the same to all provinces,

$P T$ : the ratio of provincial revenue (collection) to provincial income.

- $R=$ the inflation rate, measured by the overall retail price index in each province.

- $D C=$ the degree of fiscal decentralization, measured by the following three indicators:

$D C_{\text {cbe }}=$ the ratio of consolidated provincial spending to consolidated central spending, expressed in per capita terms

$D C_{\mathrm{be}}=$ the ratio of provincial budgetary spending to central budgetary spending, expressed in per capita terms,

$D C_{\text {ebe }}=$ the ratio of provincial extra-budgetary to central extra-budgetary spending, expressed relative to income.

We fit our growth model to these provincial-level data as follows: ${ }^{7}$

$$
Y_{s t}=\beta_{\mathrm{m}} M_{s t}+\beta_{n} N_{s t}+\beta_{\mathrm{dc}} D C_{s t}+u_{s t},
$$

where $s$ and $t$ indicate province and year, respectively. $M_{s t}$ is a set of variables always included in the regression, $N_{s t}$ is a subset of variables identified by the literature as potentially important explanatory variables of growth, $D C_{s t}$ denotes variables of interest, and finally, $u_{s t}$ denotes the error term.

The $M$-variables consist of the growth rate in total labor force $(L)$ and the tax rates $(C T$ and $P T)$. The tax rates are our aggregate measure of distortion introduced by governments to finance their spending. ${ }^{8}$ Other potentially important

\footnotetext{
${ }^{7}$ This specification follows from Barro (1990); Davoodi et al. (1995); Devarajan et al. (1996) and Davoodi, Zou (1997).

${ }^{8}$ To better capture the effect of tax distortions on provincial economic growth, we choose $C T$, the central tax rate as some measure of the overall tax rate, in addition to $P T$, the provincial tax rate.
} 
explanatory variables of growth used in many studies on economic growth are included as $N$-variables: the degree of openness $(F)$, the inflation rate $(R)$, and the investment rate $(I)$. The usual argument for including the degree of openness as a determinant of growth states that more exports lead to more efficient resource allocation as a result of external competition in the world market, whereas imports are the means to import advanced technology from developed economies (see Feder, 1983). Inflation can generate a positive effect on growth because higher inflation leads people to invest more in physical capital and cut their real-balance holdings (the Tobin portfolio-shift effect). But at the same time, inflation raises the transaction cost of economic activities (consumption and investment) and may reduce the rate of economic growth. The investment rate appears as a "mustinclude" variable in traditional specifications of growth estimation. But in the recent literature on economic growth, it is endogenous. In order to make sure that our results are robust across different specifications of regression equations, we also include the investment rate as one explanatory variable in our sensitivity analysis. To capture the impact of the pattern of budgetary expenditure by the central and provincial governments on economic growth, the composition of public expenditure by both is also included as $N$-variables.

In this study, our primary concern is with the third set of variables, $D C_{s t}$ in Eq. (1): the three indicators of fiscal decentralization, $D C_{\mathrm{be}}, D C_{\mathrm{ebe}}$, and $D C_{\mathrm{cbe}}$, which adjust for population size and income level.

\subsection{Regression results}

\subsubsection{Base case}

As our base case, we first choose the $M$-variables and one of the three indicators of fiscal decentralization, $D C_{\mathrm{be}}$, the ratio of per capita provincial budgetary spending to per capita central budgetary spending, while ignoring the potentially important $N$-variables. The results of the LSDV (least squares dummy variables) regression of the base case are:

$$
\begin{gathered}
Y_{s t}=0.341 L_{s t}-0.058 C T_{t}-0.329 P T_{s t}-0.054 D C_{\mathrm{be} s t} \\
(1.501) \quad(-1.364) \quad(-1.818) \quad(-3.617) .
\end{gathered}
$$

(Adjusted $R^{2}=0.173$, number of observations $=196$, and values of $t$-statistics appear in parentheses.) Labor growth has a positive but insignificant effect on growth. Both the central tax and provincial tax have negative, relatively insignificant, effects on growth. Our primary concern is the sign and magnitude of the coefficient for fiscal decentralization, which is -0.054 and significantly different from zero at the $1 \%$ significance level. This is surprising in light of the conventional expectation that fiscal decentralization is usually associated with positive economic growth. 


\subsubsection{Structural changes and their sensitivities}

To see whether our result is robust to changes in the conditioning information set, we conduct sensitivity tests against the three fiscal decentralization indicators in various estimations. ' In doing so, eight estimations are made along with different selections of the three $N$-variables $(F, R$, and $I)$. In estimating the impact of fiscal decentralization of extra-budgetary spending on growth, we use both $D C_{\text {be }}$ and $D C_{\text {ebe }}$ to jointly measure the degree of decentralization.

Table 2 shows the sensitivity results for each of the $M$-variables and the indicators of fiscal decentralization. For budgetary spending, the coefficients of labor growth are positive but not significantly different from zero at the conventional 5\% significance level, and the non-significance result is consistent between the lower bound and the upper bound of the labor coefficient. Similar results are observed with the coefficients of the tax rates. But the coefficient of decentralization measure, $D C_{\mathrm{be}}$, is consistently negative and significant. At the upper bound, the decentralization coefficient is -0.047 with a $t$-value of -3.413 , whereas it becomes -0.070 with a $t$-value of -4.704 at the lower bound.

Similar results are obtained for extra-budgetary spending, $D C_{\text {ebe }}$, and for consolidated spending, $D C_{\text {cbe }}$. The negative association between decentralization and growth prevails in 32 estimations although the negative significance for $D C_{\mathrm{be}}$ appears relatively weak in two estimations at the $5 \%$ significance level. The magnitude of the negative association between decentralization in extra-budgetary spending and the growth rate ranges from 0.088 to 0.101 . Moreover, the coefficients for openness and the investment rate in these estimations are positive and significant.

\subsubsection{Alternative specifications}

To further investigate the negative association between fiscal decentralization and provincial economic growth, three alternative specifications are introduced with respect to the base case: (1) different sample periods, (2) cross-province estimations based on provincial average values during 1986-92, and (3) the random-effect estimation with the generalized-least-squares (GLS) regression.

Table 3 contains the results of the above alternative specifications. First, the negative correlation between fiscal decentralization and growth remains for both additional sample periods of 1980-92 and 1985-89. The first sample period extends the base sample period (1986-92) to the beginning of the reforms. The second is selected to focus on the period of extensive fiscal decentralization. As columns (1) and (2) show, the decentralization coefficients are consistently negative and significantly different from zero at the $5 \%$ level of significance. The magnitude of the negative effect of decentralization on growth, however, varies: in the sample covering the entire reform period, the negative effect of decentraliza-

\footnotetext{
${ }^{9}$ Following Levine, Renelt (1992), we say that the result is robust if the regression coefficient remains significant and has the same sign at the extreme (lower and upper) bounds.
} 
Table 2

Sensitivity results for fiscal decentralization indicators. Dependent variable: real growth rate $(Y)$, 1986-1992

\begin{tabular}{|c|c|c|c|c|c|c|c|c|}
\hline Variable & & Coefficient & $\begin{array}{l}\text { Standard } \\
\text { error }\end{array}$ & $t$ & $R$-Square & $\begin{array}{l}\text { Adjusted } \\
R \text {-Square }\end{array}$ & $\begin{array}{l}\text { S.E. } \\
\text { regression }\end{array}$ & $\begin{array}{l}\text { Other } \\
\text { variables }\end{array}$ \\
\hline \multirow[t]{3}{*}{$L$ (Labor) } & high & 0.484 & 0.322 & 1.501 & 0.353 & 0.220 & 0.005 & $I, R$ \\
\hline & base & 0.341 & 0.324 & 1.053 & 0.305 & 0.173 & 0.045 & \\
\hline & low & 0.180 & 0.320 & 0.562 & 0.367 & 0.244 & 0.043 & $\mathrm{~F}$ \\
\hline \multirow{3}{*}{$\begin{array}{l}C T \text { (Central } \\
\text { Tax Rate) }\end{array}$} & high & 0.377 & 0.448 & 0.842 & 0.390 & 0.264 & 0.043 & $R, \mathrm{~F}$ \\
\hline & base & -0.058 & 0.424 & -1.364 & 0.305 & 0.173 & 0.045 & \\
\hline & low & -0.060 & 0.412 & -1.696 & 0.350 & 0.222 & 0.045 & $I$ \\
\hline \multirow{3}{*}{$\begin{array}{l}P T \text { (Provincial } \\
\text { Tax Rate) }\end{array}$} & high & -0.124 & 0.171 & -0.727 & 0.425 & 0.303 & 0.042 & $I, R, \mathrm{~F}$ \\
\hline & base & -0.329 & 0.181 & -1.818 & 0.305 & 0.173 & 0.045 & \\
\hline & low & -0.329 & 0.181 & -1.818 & 0.305 & 0.173 & 0.046 & \\
\hline \multirow[t]{3}{*}{$D C_{\mathrm{be}}$} & high & -0.047 & 0.014 & -3.413 & 0.367 & 0.244 & 0.043 & $\mathrm{~F}$ \\
\hline & base & -0.054 & 0.015 & -3.617 & 0.305 & 0.173 & 0.045 & \\
\hline & low & -0.070 & 0.015 & -4.704 & 0.425 & 0.303 & 0.042 & $I, R, \mathrm{~F}$ \\
\hline \multirow[t]{3}{*}{$L$ (Labor) } & high & 0.462 & 0.320 & 1.443 & 0.349 & 0.212 & 0.040 & $I, R$ \\
\hline & base & 0.328 & 0.321 & 1.019 & 0.302 & 0.166 & 0.045 & \\
\hline & low & 0.153 & 0.319 & 0.479 & 0.338 & 0.204 & 0.044 & $\mathrm{~F}$ \\
\hline \multirow{3}{*}{$\begin{array}{l}C T \text { (Central } \\
\text { Tax Rate) }\end{array}$} & high & 0.798 & 0.453 & 1.761 & 0.375 & 0.243 & 0.041 & $R, \mathrm{~F}$ \\
\hline & base & -0.128 & 0.417 & -0.306 & 0.302 & 0.166 & 0.045 & \\
\hline & low & -0.209 & 0.405 & -0.052 & 0.347 & 0.215 & 0.044 & $I$ \\
\hline \multirow{3}{*}{$\begin{array}{l}P T \text { (Provincial } \\
\text { Tax Rate }\end{array}$} & high- & 0.032 & 0.186 & -0.170 & 0.411 & 0.283 & 0.042 & $I, R, \mathrm{~F}$ \\
\hline & base & -0.251 & 0.195 & -1.288 & 0.302 & 0.166 & 0.045 & \\
\hline & low & -0.251 & 0.195 & -1.288 & 0.302 & 0.166 & 0.045 & \\
\hline \multirow[t]{3}{*}{$D C_{\text {cbe }}$} & high & -0.316 & 0.144 & -2.193 & 0.338 & 0.204 & 0.044 & $\mathrm{~F}$ \\
\hline & base & -0.387 & 0.145 & -2.660 & 0.302 & 0.166 & 0.045 & \\
\hline & low & -0.517 & 0.152 & -3.392 & 0.349 & 0.212 & 0.044 & $I, R$ \\
\hline \multirow[t]{3}{*}{$L$ (Labor) } & high & 0.494 & 0.305 & 1.622 & 0.426 & 0.303 & 0.042 & $I, R$ \\
\hline & base & 0.349 & 0.309 & 1.131 & 0.373 & 0.250 & 0.044 & \\
\hline & low & 0.205 & 0.306 & 0.669 & 0.405 & 0.283 & 0.043 & $\mathrm{~F}$ \\
\hline \multirow{3}{*}{$\begin{array}{l}C T \text { (Central } \\
\text { Tax Rate) }\end{array}$} & high & 0.263 & 0.430 & 0.613 & 0.444 & 0.326 & 0.041 & $R, \mathrm{~F}$ \\
\hline & base & -0.620 & 0.404 & -1.536 & 0.373 & 0.250 & 0.044 & \\
\hline & low & -0.750 & 0.390 & -1.923 & 0.423 & 0.305 & 0.042 & $I$ \\
\hline \multirow{3}{*}{$\begin{array}{l}P T \text { (Provincial } \\
\text { Tax Rate) }\end{array}$} & high & -0.062 & 0.163 & -0.383 & 0.485 & 0.371 & 0.040 & $I, R, \mathrm{~F}$ \\
\hline & base & -0.250 & 0.174 & -1.440 & 0.373 & 0.250 & 0.044 & \\
\hline & low & -0.250 & 0.174 & -1.440 & 0.373 & 0.250 & 0.044 & \\
\hline \multirow[t]{4}{*}{$D C_{\text {be }}$} & high & -0.025 & 0.154 & -1.603 & 0.405 & 0.283 & 0.043 & $\mathrm{~F}$ \\
\hline & base & -0.027 & 0.016 & -1.725 & 0.373 & 0.250 & 0.044 & \\
\hline & low & -0.044 & 0.015 & -2.856 & 0.485 & 0.371 & 0.040 & $I, R, \mathrm{~F}$ \\
\hline & high & -0.088 & 0.022 & -3.972 & 0.444 & 0.326 & 0.041 & $R, \mathrm{~F}$ \\
\hline \multirow[t]{2}{*}{$D C_{\text {ebe }}$} & base & -0.097 & 0.023 & -4.193 & 0.373 & 0.250 & 0.044 & \\
\hline & low & -0.101 & 0.022 & -4.512 & 0.423 & 0.305 & 0.042 & $I$ \\
\hline
\end{tabular}

Note:

1. All estimations have considered provincial fixed effects, but the results are not reported here.

2. $D C_{\text {cbe }}=$ decentralization measured by the ratio of consolidated provincial spending to consolidated central spending, expressed in per capita terms.

3. $D C_{\mathrm{be}}=$ decentralization measured by the ratio of provincial budgetary spending to central budgetary spending, expressed in per capita terms.

4. $D C_{\text {ebe }}=$ decentralization measured by the ratio of provincial extra-budgetary to central extrabudgetary spending, expressed relative to the income size.

Source: See the data Appendix A. 
Table 3

Estimates of alternative specifications. Dependent variable: real growth rate

\begin{tabular}{|c|c|c|c|c|c|c|c|}
\hline Variable & $\begin{array}{l}(1) \\
(1980-1992)\end{array}$ & $\begin{array}{l}(2) \\
(1985-1989)\end{array}$ & $\begin{array}{l}\text { (3) Base, } \\
\text { average } \\
(1986-1992)\end{array}$ & $\begin{array}{l}\text { (4) Augmented } \\
\text { base, average } \\
(1986-1992)\end{array}$ & $\begin{array}{l}\text { (5) GLS } \\
\text { (consolidated) } \\
(1986-1992)\end{array}$ & $\begin{array}{l}\text { (6) GLS } \\
\text { (budgetary) } \\
(1986-1992)\end{array}$ & $\begin{array}{l}\text { (7) GLS } \\
\text { (extra-budgetary) } \\
\text { (1986-1992) }\end{array}$ \\
\hline Constant & & & $\begin{array}{c}0.104 \\
(4.130)\end{array}$ & $\begin{array}{l}0.01 \\
(0.195)\end{array}$ & $\begin{array}{c}0.163 \\
(4.992)\end{array}$ & $\begin{array}{c}0.203 \\
(5.446)\end{array}$ & $\begin{array}{c}0.298 \\
(7.188)\end{array}$ \\
\hline$L$ (Labor) & $\begin{array}{c}0.088 \\
(0.221)\end{array}$ & $\begin{array}{c}0.863 \\
(2.448)\end{array}$ & $\begin{array}{l}-0.225 \\
(-0.406)\end{array}$ & $\begin{array}{c}0.530 \\
(1.300)\end{array}$ & $\begin{array}{c}0.262 \\
(0.865)\end{array}$ & $\begin{array}{c}0.239 \\
(0.798)\end{array}$ & $\begin{array}{c}0.278 \\
(0.977)\end{array}$ \\
\hline $\begin{array}{l}C T \\
\quad(\text { Central Tax Rate) }\end{array}$ & $\begin{array}{l}0.38 \\
(0.841)\end{array}$ & $\begin{array}{c}-0.262 \\
(3.147)\end{array}$ & & & $\begin{array}{l}-0.331 \\
(-0.839)\end{array}$ & $\begin{array}{l}-0.533 \\
(-1.342)\end{array}$ & $\begin{array}{l}-0.606 \\
(-1.603)\end{array}$ \\
\hline $\begin{array}{l}P T \\
\quad \text { (Provincial Tax Rate) }\end{array}$ & $\begin{array}{l}-0.204 \\
(-1.525)\end{array}$ & $\begin{array}{l}-0.054 \\
(-0.285)\end{array}$ & $\begin{array}{l}-0.076 \\
(-0.523)\end{array}$ & $\begin{array}{l}-0.004 \\
(-0.037)\end{array}$ & $\begin{array}{l}-0.315 \\
(-1.898)\end{array}$ & $\begin{array}{r}-0.300 \\
(1.946)\end{array}$ & $\begin{array}{l}-0.232 \\
(-1.566)\end{array}$ \\
\hline$D C_{\text {cbe }}$ & & & & & $\begin{array}{l}-0.095 \\
(-1.056)\end{array}$ & & \\
\hline$D C_{\mathrm{be}}$ & $\begin{array}{l}-0.011 \\
(-2.743)\end{array}$ & $\begin{array}{l}-0.066 \\
(-3.147)\end{array}$ & $\begin{array}{l}-0.003 \\
(-0.519)\end{array}$ & $\begin{array}{l}-0.020 \\
(-2.85)\end{array}$ & & $\begin{array}{l}-0.022 \\
(-2.164)\end{array}$ & $\begin{array}{c}0.001 \\
(0.071)\end{array}$ \\
\hline$D C_{\text {ebe }}$ & & & & & & & $\begin{array}{l}-0.090 \\
(-4.501)\end{array}$ \\
\hline$R$ (Inflation Rate) & & & & $\begin{array}{c}0.194 \\
(0.324)\end{array}$ & & & \\
\hline$F$ (Openness) & & & & $\begin{array}{r}0.153 \\
(5.21)\end{array}$ & & & \\
\hline$I$ (Investment) & & & & $\begin{array}{c}0.140 \\
(2.33)\end{array}$ & & & \\
\hline Number of observations & 308 & 134 & 28 & 28 & 196 & 196 & 196 \\
\hline $\begin{array}{l}\text { Provincial fixed effect } \\
\text { Adjusted } R \text {-square }\end{array}$ & $\begin{array}{l}\text { Not included } \\
0.039\end{array}$ & $\begin{array}{l}\text { Not included } \\
0.182\end{array}$ & $\begin{array}{l}\text { Not included } \\
-0.051\end{array}$ & $\begin{array}{l}\text { Not included } \\
0.512\end{array}$ & Included & Included & Included \\
\hline Residual SS & & & & & 0.349 & 0.341 & 0.306 \\
\hline S.E. Regression & 0.090 & 0.043 & 0.022 & 0.015 & 0.043 & 0.043 & 0.040 \\
\hline
\end{tabular}

1. Values of $t$-statistics appear in parentheses.

2. $D C_{\text {cbe }}=$ decentralization measured by the ratio of consolidated provincial spending to consolidated central spending, expressed in per capita terms.

3. $D C_{\mathrm{be}}=$ decentralization measured by the ratio of provincial budgetary spending to central budgetary spending, expressed in per capita terms.

4. $D C_{\text {ebe }}=$ decentralization measured by the ratio of provincial extra-budgetary to central extra-budgetary spending, expressed relative to the income size.

Source: See the data Appendix A. 
tion on growth appears weaker than in the base case, whereas in the sample of extensive decentralization, the negative effect becomes even stronger.

To introduce the second alternative specification, we estimate the base equation and the augmented base equation (including all the $M$ - and $N$-variables) with average provincial data during 1986-92. The estimation of the base equation is shown in Column (3): the growth impact of decentralization is still negative, but not significant. The estimation of the augmented base equation is reported in Column (4), which presents a negative and significant coefficient for fiscal decentralization. In this column, we also note that the inflation rate has a positive and non-significant effect on growth, the effect of provincial openness is positive and statistically very significant, and the estimated coefficient of the investment rate is positive and significant.

The robustness of our results is further examined with random-effect estimations. Negative and significant coefficients for fiscal decentralization are found in two indicators for budgetary and extra-budgetary spending respectively as shown in columns (6) and (7). Column (5) shows a negative and insignificant sign for $D C_{\text {cbe }}$. The overall results from the random-effect estimations show their consistency with the fixed-effect estimations.

\subsubsection{Impact of intersectoral allocation of central and provincial government spending on growth}

Next we examine the expenditure pattern of central and provincial governments and its impact on growth in the context of fiscal decentralization. As an alternative, we measure the overall distortion in the economy by using the national tax rate, $N T$, defined as the ratio of national budgetary revenue to national GDP. ${ }^{10}$ For fiscal decentralization, we use $D C$, measured by the ratio of provincial budgetary spending to central budgetary spending. ${ }^{11}$ To measure the intersectoral allocation of government spending, we use the following variables:

- $C A D M=$ the share of central budgetary spending on administration out of total central budgetary spending.

- $C D E V=$ the share of central budgetary spending on development out of total central budgetary spending ${ }^{12}$.

\footnotetext{
${ }^{10}$ Our results also hold qualitatively for the two measures of distortions, $C T$ and $P T$, in our previous estimations.

${ }^{11}$ Since the data on functional distribution of extra-budgetary spending are not available, we limit our intersectoral analysis to budgetary spending only.

${ }^{12}$ Including expenses on capital construction, enterprise upgrading, technical R and D, and support for the agricultural sector.
} 
- $C D F N=$ the share of central budgetary spending on defense out of total central budgetary spending.

- $C H U M=$ the share of central budgetary spending on human capital out of total central budgetary spending ${ }^{13}$.

- $P A D M=$ the share of provincial budgetary spending on administration out of total provincial budgetary spending in each province.

- $P D E V=$ the share of provincial budgetary spending on development out of total provincial budgetary spending in each province.

- $P U R B=$ the share of provincial budgetary spending on urban maintenance out of total provincial budgetary spending in each province ${ }^{14}$.

- $P H U M=$ the share of provincial budgetary spending on human capital out of total provincial budgetary spending in each province.

The regression results are shown in Table $4 .{ }^{15}$ The first column shows the estimates when only $D C$, spending variables, and the constant term are included. We find that fiscal decentralization is again negatively associated with real output growth; the coefficient is -1.79 and significant at the conventional $5 \%$ level.

In terms of the growth impact of government expenditures, the results for central and local government spending yield different pictures. Central spending on administration and development has a positive and significant impact on growth. For local expenditures, the growth impact of spending on administration and development is negative and significant. Both central and local government spending on human capital are positively but insignificantly associated with growth. Central government spending for defense gives an estimated coefficient that is negative and significant. Local government spending on urban maintenance and development gives an estimated coefficient that is positive but insignificant.

The second column shows estimates when provincial fixed effects are included. The estimate for fiscal decentralization, $D C$, is still negative and significant. The relationship between growth and government spending found in the first column remains unchanged.

Columns 3, 4, and 5 report estimation results when variables such as the investment rate, the share of foreign trade, and the inflation rate are included. The results show that the negative correlation between fiscal decentralization and growth is consistently stable under various control scenarios. The estimation results of government-spending variables reported in Column (1) do not change significantly.

\footnotetext{
${ }^{13}$ Including expenses on culture, education, health care, and science.

${ }^{14}$ Including urban maintenance and urban youth employment.

${ }^{15}$ The sample period here is 1987 to 1993 .
} 
Table 4

Effect of intersectoral and intergovernmental allocation of budgetary expenditure: national perspective, 1987-1993. Dependent variable: real growth of provincial GDP

\begin{tabular}{|c|c|c|c|c|c|}
\hline Independent variables & (1) & (2) & (3) & (4) & $(5)$ \\
\hline Constant & $\begin{array}{l}3.123 \\
4.018\end{array}$ & & & & \\
\hline$N T$ (National tax rate) & $\begin{array}{l}-10.055 \\
(-3.311)\end{array}$ & $\begin{array}{l}-10.634 \\
(-3.801)\end{array}$ & $\begin{array}{l}-10.792 \\
(-3.836)\end{array}$ & $\begin{array}{l}-10.872 \\
(-4.064)\end{array}$ & $\begin{array}{l}-14.699 \\
(-2.514)\end{array}$ \\
\hline$L$ (Labor) & $\begin{array}{c}0.296 \\
(0.902)\end{array}$ & $\begin{array}{c}0.289 \\
(0.697)\end{array}$ & $\begin{array}{c}0.245 \\
(0.585)\end{array}$ & $\begin{array}{c}0.274 \\
(0.640)\end{array}$ & $\begin{array}{c}0.295 \\
(0.685)\end{array}$ \\
\hline$D C$ & $\begin{array}{c}-1.788 \\
(-2.723)\end{array}$ & $\begin{array}{c}-1.996 \\
(-3.291)\end{array}$ & $\begin{array}{c}-1.959 \\
(-3.229)\end{array}$ & $\begin{array}{c}-1.993 \\
(-3.428)\end{array}$ & $\begin{array}{c}-2.504 \\
(-2.765)\end{array}$ \\
\hline$C A D M$ & $\begin{array}{c}6.932 \\
(4.094)\end{array}$ & $\begin{array}{c}7.481 \\
(4.626)\end{array}$ & $\begin{array}{c}7.867 \\
(4.595)\end{array}$ & $\begin{array}{c}7.548 \\
(4.562)\end{array}$ & $\begin{array}{c}9.216 \\
(3.283)\end{array}$ \\
\hline$C D E V$ & $\begin{array}{c}1.074 \\
(2.833)\end{array}$ & $\begin{array}{c}1.118 \\
(3.207)\end{array}$ & $\begin{array}{c}1.149 \\
(3.298)\end{array}$ & $\begin{array}{c}1.205 \\
(3.614)\end{array}$ & $\begin{array}{c}1.681 \\
(2.311)\end{array}$ \\
\hline$C D F N$ & $\begin{array}{c}-6.226 \\
(-6.138)\end{array}$ & $\begin{array}{c}-6.134 \\
(-6.492)\end{array}$ & $\begin{array}{c}-6.519 \\
(-6.173)\end{array}$ & $\begin{array}{c}-6.367 \\
(-6.011)\end{array}$ & $\begin{array}{c}-7.795 \\
(-3.526)\end{array}$ \\
\hline CHUM & $\begin{array}{c}0.469 \\
(0.609)\end{array}$ & $\begin{array}{c}0.033 \\
(0.044)\end{array}$ & $\begin{array}{c}0.153 \\
(0.206)\end{array}$ & $\begin{array}{c}-0.040 \\
(-0.056)\end{array}$ & $\begin{array}{c}-0.377 \\
(-0.442)\end{array}$ \\
\hline$P A D M$ & $\begin{array}{c}-0.443 \\
(-4.176)\end{array}$ & $\begin{array}{c}-0.393 \\
(-2.175)\end{array}$ & $\begin{array}{c}-0.404 \\
(-2.201)\end{array}$ & $\begin{array}{c}-0.334 \\
(-1.833)\end{array}$ & $\begin{array}{c}-0.332 \\
(-1.813)\end{array}$ \\
\hline$P D E V$ & $\begin{array}{c}-0.142 \\
(-1.446)\end{array}$ & $\begin{array}{c}-0.177 \\
(-1.373)\end{array}$ & $\begin{array}{c}-0.201 \\
(-1.520)\end{array}$ & $\begin{array}{c}-0.246 \\
(-1.952)\end{array}$ & $\begin{array}{c}-0.254 \\
(-2.006)\end{array}$ \\
\hline PHUM & $\begin{array}{c}0.505 \\
(3.911)\end{array}$ & $\begin{array}{c}0.179 \\
(1.044)\end{array}$ & $\begin{array}{c}0.294 \\
(1.581)\end{array}$ & $\begin{array}{c}0.338 \\
(1.899)\end{array}$ & $\begin{array}{c}0.304 \\
(1.65)\end{array}$ \\
\hline$P U R B$ & $\begin{array}{c}0.074 \\
(0.358)\end{array}$ & $\begin{array}{c}0.330 \\
(0.935)\end{array}$ & $\begin{array}{c}0.293 \\
(0.810)\end{array}$ & $\begin{array}{c}0.149 \\
(0.400)\end{array}$ & $\begin{array}{c}0.155 \\
(0.413)\end{array}$ \\
\hline$I$ (investment) & & & $\begin{array}{c}-0.045 \\
(-0.536)\end{array}$ & $\begin{array}{c}0.043 \\
(0.462)\end{array}$ & $\begin{array}{c}0.055 \\
(0.581)\end{array}$ \\
\hline$F$ (foreign trade) & & & & $\begin{array}{c}0.094 \\
(1.115)\end{array}$ & $\begin{array}{c}0.068 \\
(0.750)\end{array}$ \\
\hline$R$ (interest rate) & & & & & $\begin{array}{c}-0.120 \\
(-0.737)\end{array}$ \\
\hline Number of observations & 136 & 136 & 135 & 125 & 125 \\
\hline Provincial fixed effect & Not included & included & included & included & included \\
\hline$R$-Square & 0.634 & 0.774 & 0.780 & 0.792 & 0.793 \\
\hline Adjusted $R$-Square & 0.601 & 0.682 & 0.686 & 0.689 & 0.688 \\
\hline S.E. of regression & 0.037 & 0.033 & 0.033 & 0.030 & 0.030 \\
\hline
\end{tabular}

Note: $t$-statistics are in parentheses.

Source: See the data Appendix A.

\section{Conclusions}

The negative association between fiscal decentralization and provincial economic growth has been found to be consistently significant and robust in China. This finding is surprising in light of the conventional wisdom that fiscal decentralization usually makes a positive contribution to local economic growth. 
Perhaps this is understandable given the current stage of economic development in China, where the central government is constantly constrained by the limited resources for public investment in national priorities such as highways, railways, power stations, telecommunications, and energy. Such key infrastructure projects may have a far more significant impact on growth across provinces than their counterparts in each province. This is supported by results shown in Table 4, in which the association between central government development spending and economic growth is positive and significant. At the same time, provincial government development spending is negatively associated with growth.

This finding also has some implications for other developing countries and transition economies pursuing fiscal decentralization. The merits of fiscal decentralization have to be measured relative to the existing revenue and expenditure assignments and the stage of economic development. The central government may be in a much better position to undertake public investment with nation-wide externalities in the early stages of economic development. More importantly, if local shares in total fiscal revenue and expenditure are already high, further decentralization may result in slower overall economic growth. In this connection, the dangers of decentralization put forward by Prud'homme (1995) seem to be empirically relevant.

\section{Acknowledgements}

For comments and suggestions, we thank Hamid Davoodi, Martha de Melo, Shantayanan Devarajan, Gang Fan, Bert Hofman, John H. Jia, Hongyi Li, Stephen McGurk, Ronald McKinnon, Charles McLure, Richard Newfarmer, Yingyi Qian, Terry Sicular, Hedy Sladovich, Berry Weingast, Christine Wong, Danyang Xie, and seminar participants at Stanford University and the World Bank. We are most grateful to two referees of this journal for their detailed and constructive suggestions, which led to a substantial revision of this paper. We also acknowledge financial assistance from the Washington Center of China Studies, the Ford Foundation, and the World Bank (research grant RPO 680-02). The findings, interpretations, and conclusions expressed in this paper are entirely those of the authors. They do not necessarily represent the views of the World Bank, its Executive Directors, or the countries they represent.

\section{Appendix A}

Our empirical estimations are based on annual data for 28 provinces. Data sources are all official publications in China. Although over 100 volumes of statistical publications are involved, major data sources include China Statistical 
Yearbook and provincial statistical yearbooks for various years. Variables used for estimations are listed below with their data sources. Names of provincial areas included in our estimations are also listed.

$Y=$ the real growth rate of provincial income, measured at constant price level. Source: For 1980-1985: China National Income Statistics 1949-1985 (Guomin Shouru Tongji Ziliao Huibian 1949-1985); for 1985-1992: China Statistical Yearbook (Zhongguo Tongji Nianjian) various issues.

$L=$ the growth rate of the provincial labor force.

Source: For 1980-1985, various volumes of provincial statistical yearbooks; for 1986-1992: China Statistical Yearbook (Zhongguo Tongji Nianjian), various issues.

$I=$ the provincial investment rate, measured by the rate of accumulation in fixed assets and circulating funds.

Source: For 1980-1985: China National Income Statistics 1949-1985 (Guomin Shouru Tongji Ziliao Huibian 1949-1985); for 1985-1992: China Statistical Yearbook (Zhongguo Tongji Nianjian), various issues.

$F=$ the degree of openness of provincial economy, measured by the share of total volume of foreign trade (exports and imports) in provincial income.

Source: Almanac of China's Foreign Economic Relations and Trade (Zhongguo Duiwai Jingji Maoyi Nianjian), various issues in 1984-1994/95.

$T A X=$ the degree of distortion in provincial economy, measured by $N T$, the national tax rate, $C T$, the central tax rate, and $P T$, the ratio of provincial revenue collection in provincial income.

Source: Various volumes of provincial statistical yearbooks.

$R=$ the inflation rate, measured by the overall social retail price index in each province.

Source: China Statistical Yearbook (Zhongguo Tongji Nianjian), various issues. $D C_{\text {cbe }}=$ decentralization measured by the ratio of per capita provincial spending to per capita central spending.

Source: For provincial population: various volumes of provincial statistical yearbooks; for the central government, national population is used, China Statistical Yearbook (Zhongguo Tongji Nianjian), various issues.

$D C_{\mathrm{be}}=$ decentralization measured by the ratio of per capita provincial budgetary spending to per capita central budgetary spending.

Source: See sources of budgetary spending and of population.

$D C_{\text {ebe }}=$ decentralization measured by the ratio of provincial extra-budgetary spending to central extra-budgetary spending, expressed relative to income.

Source: See sources for provincial income and of extra-budgetary spending. $D C=$ the ratio of local budgetary spending relative to central budgetary spending.

Source: See sources for budgetary spending. 
Data sources for the following variables are derived by the authors from various provincial statistical yearbooks, and Ministry of Finance, Finance Yearbook of China (Zhongguo Caizhang Tongji Nianjian), 1993, and 1994; Ministry of Finance, China Government Finance Statistics (Zhongguo Caizheng Tongji) 19501985, 1950-1988, and 1950-1991.

$C A D M=$ the share of central budgetary spending on administration out of total central budgetary spending.

$C D E V=$ the share of central budgetary spending on development out of total central budgetary spending, including expenses on capital construction, enterprise upgrading, technical $\mathrm{R}$ and $\mathrm{D}$, and support for the agricultural sector. $C D F N=$ the share of central budgetary spending on defense out of total central budgetary spending.

$C H U M=$ the share of central budgetary spending on human capital out of total central budgetary spending, including expenses on culture, education, public health care, and science.

$P A D M=$ the share of provincial budgetary spending on administration out of total provincial budgetary spending in each province.

$P D E V=$ the share of provincial budgetary spending on development out of total provincial budgetary spending in each province.

$P U R B=$ the share of provincial budgetary spending on urban maintenance out of total provincial budgetary spending in each province.

$P H U M=$ the share of provincial budgetary spending on human capital out of total provincial budgetary spending in each province.

\section{List of provincial areas:}

Beijing, Tianjin, Hebei, Shanxi, Neimenggu (Inner Mongolia), Liaoning, Jilin, Heilongjiang, Shanghai, Jiangsu, Zhejiang, Anhui, Fujian, Jiangxi, Shandong, Henan, Hubei, Hunan, Guangdong, Guangxi, Sichuan, Guizhou, Yunnan, Shaanxi, Gansu, Qinghai, Ningxia, and Xinjiang.

\section{References}

Bahl, R.W., Linn, J., 1992. Urban public finance in developing countries. Oxford University Press, New York.

Bahl, R.W., Wallich, C., 1992. Intergovernmental fiscal relations in China. Working Papers, Policy Research Department, World Bank, Washington D.C.

Barro, R., 1990. Government spending in a simple model of endogenous growth. Journal of Political Economy 98, S103-S125. 
Bird, R.M., Wallich, C., 1993. Fiscal decentralization and intergovernmental relations in transition economies: Towards a systematic framework of analysis. Country Economics Department Working Paper, World Bank, Washington D.C.

Bird, R.M., 1993. Threading the fiscal labyrinth: Some issues in fiscal decentralization. National Tax Journal XLVI (2), 207-227.

Davoodi, H., Zou, H., 1997. Fiscal decentralization and economic growth: A cross-county study. forthcoming, Journal of Urban Economics.

Davoodi, H., Xie, D., Zou, H.-f., 1995. Fiscal decentralization and economic growth in the United States. Policy Research Department, World Bank, Washington, D.C.

Devarajan, S., Vinaya, S., Zou, H., 1996. The composition of public spending and economic growth. Journal of Monetary Economics 37, 313-344.

Feder, G., 1983. On exports and economic growth. Journal of Development Economics 12, 59-73.

Gramlich, E.M., 1993. A policy-maker's guide to fiscal decentralization. National Tax Journal XLVI (2), 229-235.

Levine, R., Renelt, D., 1992. A sensitivity analysis of cross-country growth regressions. American Economic Review 82 (4), 942-963.

Oates, W.E., 1972. Fiscal federalism. Harcourt Brace Jovanovich, New York.

Oates, W.E., 1993. Fiscal decentralization and economic development. National Tax Journal XLVI (2), 237-243.

Prud'homme, R., 1995. The dangers of decentralization. The World Bank Research Observer, World Bank, Washington D.C.

Wang, S., A. Hu, 1993. Report on China's state capacity (Zhongguo guojia nengli baogao). Shengyang, China: Liaoning People's Press.

Wong, C.P.W., Heady, C., Woo, W.T., 1993. Economic reform and fiscal management in China: Report of technical assistance project. Asian Development Bank and Ministry of Finance of China.

World Bank, 1990. Revenue mobilization and tax policy. A World Bank Country Study, World Bank, Washington D.C.

World Bank, 1992. China: Reforming intergovernmental fiscal relations. World Bank Discussion Papers, China and Mongolia Department, Washington D.C.

World Bank, 1995. Macroeconomic stability in a decentralized economy. China and Mongolia Department, World Bank, Washington D.C.

World Bank, 1996. The Chinese economy: Fighting inflation, deepening reforms. China and Mongolia Department, World Bank, Washington D.C.

Zhou, X., Yang, Z., 1992. Fiscal management and tax system in China: Problems and solutions (Zhongguo caishui tizhi de wenti yu chulu). Tianjin People's Press, Tianjin, China. 